\title{
Analysis of Nutritional Composition in 23 Kinds of Edible Fungi
}

\author{
Qiannan Yu, ${ }^{1}$ Meijuan Guo, ${ }^{1}$ Bin Zhang, ${ }^{1}$ Hao Wu, ${ }^{1}$ Yan Zhang $\mathbb{D}^{1,2}$ and Lantian Zhang ${ }^{1}$ \\ ${ }^{1}$ Hebei Food Inspection and Research Institute, Hebei Food Safety Key Laboratory, Hebei, Shijiazhuang 050000, China \\ ${ }^{2}$ Hebei Key Laboratory of Forensic Medicine, College of Forensic Medicine, Hebei Medical University, \\ Shijiazhuang 050017, China \\ Correspondence should be addressed to Yan Zhang; snowwinglv@126.com and Lantian Zhang; zlt_m@126.com
}

Received 7 September 2020; Revised 24 September 2020; Accepted 28 September 2020; Published 26 October 2020

Academic Editor: Fatma M. El-Demerdash

Copyright (C) 2020 Qiannan Yu et al. This is an open access article distributed under the Creative Commons Attribution License, which permits unrestricted use, distribution, and reproduction in any medium, provided the original work is properly cited.

\begin{abstract}
To explore the differences in the main nutritional composition of 23 kinds of common edible fungi in the market, the moisture, ash, protein, fat, dietary fiber, carbohydrates, polysaccharides, and energy were analyzed using national standard methods. The results showed that the 23 kinds of edible fungi varied greatly in nutritional composition. Based on dry weight, the moisture content was $6.9 \sim 15.5 \mathrm{~g} / 100 \mathrm{~g}$, the ash content ranged from 1.3 to $10.1 \mathrm{~g} / 100 \mathrm{~g}$, the protein content ranged from 8.5 to $36.9 \mathrm{~g} / 100 \mathrm{~g}$, the fat content was $0.5 \sim 3.9 \mathrm{~g} / 100 \mathrm{~g}$, the dietary fiber content was between $14.4 \sim 70.2 \mathrm{~g} / 100 \mathrm{~g}$, the carbohydrate content is $0.5 \sim 37.3 \mathrm{~g} / 100 \mathrm{~g}$, the polysaccharide content was $2.1 \sim 8.3 \mathrm{~g} / 100 \mathrm{~g}$, and the energy is about $751 \sim 1322100 \mathrm{~g} / \mathrm{kJ}$. All the $23 \mathrm{kinds}$ of edible fungi can be regarded as high-protein low-fat foods, which have their own advantages in terms of nutritional value. This study provides reference for people to use edible fungi in a more scientific and reasonable way.
\end{abstract}

\section{Introduction}

Edible fungus is a general term for a large class of macrofungus that are rich in nutrients and available for consumption and medicinal purposes [1]. China has very rich edible fungus resources and is one of the earliest countries to cultivate and utilize edible fungi. According to records, the earliest edible fungus cultivated by human is fungus, which originated in China in about 600 A.D. In 1902, the tissue separation method was successful in cultivating Agaricus bisporus strains. Since then, the cultivation of edible fungi has become scientific. Edible fungi contain almost all the nutrients required by the human body and are considered to be the third food source just after plant-based and animalbased foods $[2,3]$. They are not only rich in nutrients such as protein, fat, cellulose, and polysaccharide [4] but also contain health ingredients such as minerals, amino acids, and nucleotides. They are helpful in enhancing human immunity, antitumor, lowering blood lipid, and other medicinal functions [5]. As people pay more attention to food nutrition, edible fungi have become a common food on the table. To explore the content of various nutrients in edible fungi is of great significance in guiding people to improve their dietary structures and health conditions. This study determined 23 kinds of common edible fungi in the market for the content of moisture, ash, protein, fat, dietary fiber, carbohydrate, energy, and polysaccharides thereof and analyzed their nutritional value, providing a reference for people to reasonably mix their diets.

\section{Materials and Methods}

2.1. Materials and Reagents. Twenty-three kinds of edible fungi are as follows: dried samples of Tricholoma, Shiitake mushroom, Pleurotus eryngii, Dictyophora indusiata (Vent. ex Pers) Fisch, Agrocybe aegerita, Ganoderma lucidum (Leyss. ex Fr.) Karst., Yanshan Agaric, Pholiota nameko Ito ex Imai., Hericium erinaceus, Copyinds comatus (MUII. Fr) Gray, Tremella, Cordyceps militaris, Lentinus edodes (Berk.) Sing, Auricularia auricula (L.ex Hook.) under wood, Agaricus blazei Murrill, Volvariella volvacea (Bull.:Fr.) Sing., Morchella esculenta, Griflola frondosa, Arimillaria mellea, Boletus, Russula vinosa Lindblad, and Sparassis crispa.

The reagents used are as follows: absolute ethanol, concentrated sulfuric acid, sodium hydroxide, boric acid, copper sulfate, potassium sulfate, hydrochloric acid, acetone, 
absolute ether, methyl red-bromocresol green mixed indicators, etc., all of which are analytical reagents (Tianjin Kemiou Chemical Reagent, Tianjin, China), petroleum ether, analytical reagent (Damao Chemical Reagent, Tianjin, China), 2-(N-morpholino)ethanesulfonic acid, tris(hydroxymethyl)aminomethane, glucose standard substance (Sigma Chemical, USA); diatomaceous earth, pickling no. C8656 (Sigma Chemical, USA), thermostable $\alpha$-amylase solution (unit of enzyme activity: $30 \mathrm{U} / \mathrm{mg}$ ), protease solution (unit of enzyme activity: $100 \mathrm{U} / \mathrm{mg}$ ), and amyloglucosidase solution (unit of enzyme activity: $100 \mathrm{U} / \mathrm{mg}$ ) (Sigma Chemical, USA).

2.2. Apparatus and Equipment. The apparatus and equipment used are as follows: 101-3AB electrothermal blast drying oven (Taisite Instrument, Tianjin, China); TSX1200 muffle furnace (Cinite Technology, Beijing, China); Kjeltec8400 automatic Kjeldahl apparatus (Foss, Denmark); UV2700 UV-VIS spectrophotometer (Shimadzu, Japan); MS204S/01 electronic analytical balance (METTLER TOLEDO Instrument, Shanghai, China); $\mathrm{HH}-4$ digital thermostatic water bath (Guohua Electric Appliance, Changzhou, China); PHS-3C pH meter (INESA Scientific Instrument, Shanghai, China); and TDFi automatic dietary fiber analyzer (ANKOM, USA).

\subsection{Test Methods}

2.3.1. Preparation of Samples. Samples were cut into small pieces with a scissor, placed in the drying oven at $80^{\circ} \mathrm{C}$ and dried until it became crisp, and then put in a desiccator to cool and immediately crushed. The crushed samples were sieved by a sieve with the mesh size of $0.9 \mathrm{~mm}$. The parts that failed to pass the sieve were crushed again or sieved again after ground in a mortar until all samples passed through the sieve. The dry powder were collected and placed in a sealed container and then stored in a dry place for later use.

2.3.2. Determination of Nutritional Composition. The moisture content was determined according to the Method I Direct drying method in GB 5009.3-2016; the ash content was determined according to the Method I in GB 5009.42016; the protein content was determined according to the Method I Kjeldahl method in GB 5009.5-2016; the fat content was determined according to the Method II acid hydrolysis method in GB 5009.6-2016; the dietary fiber content was determined according to the enzymatic gravimetric method in GB 5009.88-2014; the polysaccharide content was determined according to GB/T 15672-2009; the carbohydrate and energy were calculated according to $\mathrm{GB} / \mathrm{Z}$ 21922-2008.

2.3.3. Data Processing Method. Excel 2010 was used for data processing and plotting.

\section{Results and Analysis}

3.1. Determination Results of Nutrient Content. The content of moisture, ash, protein, fat, dietary fibers, carbohydrates, polysaccharides, and energy of the 23 kinds of edible fungi samples are shown in Table 1.

3.2. Analysis and Discussion. The determination results showed that the nutrient content in each edible fungus varies greatly. For the same kind of edible fungus, basically, the one with a high protein content has a low dietary fiber content; the similar negative correlation was also found between the carbohydrates content and the dietary fibers content.

Moisture content directly affects the freshness, flavor, and storage performance of edible fungus. Too much moisture will cause edible fungus to perish and deteriorate during storage, which will then cause poisoning after eating; too little water will cause the pileus to roll up, accompanying a high degree of lignification and a decline in quality. As it can be seen in Table 1 and Figure 1, the moisture contents of edible fungi were about $6.9 \sim 15.5 \mathrm{~g} / 100 \mathrm{~g}$. Among the 23 kinds of edible fungi samples, there was little difference in the moisture content of Morchella esculenta, Griflola frondosa, Arimillaria mellea, Boletus, and Cordyceps militaris, all of which were around $12.0 \mathrm{~g} / 100 \mathrm{~g}$.

Ash content reflects the content of minerals in edible fungus. Mineral elements are involved in constituting bones, hemoglobin, and cytochrome; maintaining osmotic pressure and acid-base balance in the body; and also acting as an auxiliary factor of enzymes to play a role in maintaining the normal physiological function of the human body, promoting growth and development, and resisting diseases. A variety of trace elements can also protect biological membrane, benefit smooth blood, and inhibit tumor cell activity [6]. As it could be seen from Table 1 and Figure 2, among the 23 kinds of edible fungal samples, Volvariella volvacea (Bull:: Fr.) Sing. had the highest ash content, $10.08 \mathrm{~g} / 100 \mathrm{~g}$, and Lentinus edodes (Berk.) Sing had the lowest ash content, $1.27 \mathrm{~g} / 100 \mathrm{~g}$, respectively. There was little difference in the ash content of Agaricus blazei Murrill, Morchella esculenta, and Boletus, all of which were around $7.0 \mathrm{~g} / 100 \mathrm{~g}$.

Protein is an essential nutrient in human life activities, helping the formation and growth of tissues and constitution or repair of human tissues. Table 1 and Figure 3 showed that the protein contents of edible fungi were about $8.5 \sim 36.9 \mathrm{~g} /$ $100 \mathrm{~g}$, which were much higher than those in vegetables, fruits, and grains. The protein content varied in different edible fungus species. Tricholoma had the highest protein content, $36.87 \mathrm{~g} / 100 \mathrm{~g}$, and Tremella had the lowest protein content, $8.46 \mathrm{~g} / 100 \mathrm{~g}$, respectively. The study of Yue et al [7] showed that Tricholoma was rich in protein, containing $162.0 \mathrm{~g}$ of protein per $500 \mathrm{~g}$, which was close to the determined value herein. In addition, Tricholoma contains a complete range of essential amino acids and is a good source of raw materials for preparing peptides.

Fat is one of the essential substances for function of life. Low-fat and low-sugar foods have become a symbol of healthy foods, and edible fungi are included in low-fat foods. 
TABLE 1: Determination results of nutrient content of 23 kinds of edible fungi.

\begin{tabular}{|c|c|c|c|c|c|c|c|c|c|}
\hline $\begin{array}{l}\text { Serial } \\
\text { number }\end{array}$ & Name & $\begin{array}{c}\text { Moisture, } \\
\mathrm{g} / 100 \mathrm{~g}\end{array}$ & $\begin{array}{l}\text { Ash, } \\
\text { g/100 g }\end{array}$ & $\begin{array}{l}\text { Protein, } \\
\mathrm{g} / 100 \mathrm{~g}\end{array}$ & Fat, $g / 100 \mathrm{~g}$ & $\begin{array}{c}\text { Nutrients } \\
\text { Dietary } \\
\text { fibers, } g / 100 \mathrm{~g}\end{array}$ & $\begin{array}{c}\text { Carbohydrates, } \\
\mathrm{g} / 100 \mathrm{~g} \\
\end{array}$ & $\begin{array}{c}\text { Polysaccharides, } \\
\mathrm{g} / 100 \mathrm{~g}\end{array}$ & $\begin{array}{l}\text { Energy, } \\
100 \mathrm{~g} / \mathrm{kJ}\end{array}$ \\
\hline 1 & Tricholoma & 13.77 & 5.40 & 36.87 & 1.86 & 16.5 & 25.60 & 3.43 & 1263 \\
\hline 2 & $\begin{array}{c}\text { Shiitake } \\
\text { mushroom }\end{array}$ & 15.38 & 3.81 & 17.95 & 0.94 & 32.1 & 29.82 & 6.35 & 1104 \\
\hline 3 & $\begin{array}{l}\text { Pleurotus } \\
\text { eryngii }\end{array}$ & 9.16 & 6.40 & 19.15 & 0.56 & 27.5 & 37.23 & 6.85 & 1199 \\
\hline 4 & $\begin{array}{c}\text { Dictyophora } \\
\text { indusiata } \\
\text { (Vent.ex Pers) } \\
\text { Fisch }\end{array}$ & 14.50 & 6.65 & 18.25 & 0.86 & 33.5 & 26.24 & 5.87 & 1056 \\
\hline 5 & $\begin{array}{c}\text { Agrocybe } \\
\text { aegerita } \\
\text { Ganoderma }\end{array}$ & 10.62 & 5.82 & 24.79 & 1.18 & 31.1 & 26.49 & 3.74 & 1164 \\
\hline 6 & $\begin{array}{l}\text { lucidum (Leyss. } \\
\text { ex Fr.) Karst }\end{array}$ & 15.51 & 3.85 & 9.31 & 0.59 & 70.2 & 0.54 & 2.11 & 751 \\
\hline 7 & $\begin{array}{c}\text { Yanshan } \\
\text { Agaric } \\
\text { Pholiota }\end{array}$ & 10.79 & 8.10 & 11.03 & 0.48 & 63.2 & 6.40 & 6.83 & 820 \\
\hline 8 & $\begin{array}{c}\text { nameko Ito ex } \\
\text { Imai. }\end{array}$ & 10.48 & 5.42 & 17.55 & 1.22 & 33.8 & 31.53 & 7.07 & 1150 \\
\hline 9 & $\begin{array}{l}\text { Hericium } \\
\text { erinaceus } \\
\text { Copyinds }\end{array}$ & 10.68 & 5.27 & 9.55 & 0.78 & 47.0 & 26.72 & 5.81 & 1021 \\
\hline 10 & $\begin{array}{c}\text { comatus } \\
\text { (MUII. Fr) } \\
\text { Gray }\end{array}$ & 10.81 & 5.31 & 30.90 & 1.26 & 14.4 & 37.32 & 5.38 & 1322 \\
\hline 11 & Tremella & 10.90 & 9.43 & 8.46 & 1.98 & 63.7 & 5.53 & 8.29 & 821 \\
\hline 12 & $\begin{array}{l}\text { Cordyceps } \\
\text { militaris } \\
\text { Lentinus }\end{array}$ & 10.60 & 5.23 & 25.41 & 1.70 & 20.8 & 36.26 & 6.39 & 1278 \\
\hline 13 & $\begin{array}{c}\text { edodes (Berk.) } \\
\text { Sing }\end{array}$ & 11.59 & 1.27 & 23.29 & 1.06 & 33.6 & 29.19 & 5.14 & 1200 \\
\hline 14 & Agaric & 13.93 & 3.98 & 11.06 & 0.46 & 57.6 & 12.97 & 6.76 & 886 \\
\hline 15 & $\begin{array}{c}\text { Agaricus blazei } \\
\text { Murrill }\end{array}$ & 9.15 & 7.10 & 26.60 & 1.98 & 22.9 & 32.27 & 4.26 & 1257 \\
\hline 16 & $\begin{array}{c}\text { Volvariella } \\
\text { volvacea (Bull.: } \\
\text { Fr.) Sing. }\end{array}$ & 10.24 & 10.08 & 28.10 & 1.19 & 20.7 & 29.69 & 5.83 & 1192 \\
\hline 17 & $\begin{array}{l}\text { Morchella } \\
\text { esculenta }\end{array}$ & 12.72 & 7.25 & 25.85 & 3.89 & 22.4 & 27.89 & 5.14 & 1237 \\
\hline 18 & $\begin{array}{l}\text { Griflola } \\
\text { frondosa }\end{array}$ & 12.41 & 5.19 & 15.60 & 2.91 & 36.2 & 27.69 & 6.24 & 1133 \\
\hline 19 & $\begin{array}{c}\text { Arimillaria } \\
\text { mellea }\end{array}$ & 12.35 & 9.17 & 18.09 & 3.89 & 28.2 & 28.30 & 5.31 & 1158 \\
\hline 20 & Boletus & 12.16 & 7.04 & 23.99 & 1.95 & 31.0 & 23.86 & 4.94 & 1134 \\
\hline 21 & $\begin{array}{l}\text { Russula vinosa } \\
\text { Lindblad }\end{array}$ & 8.20 & 8.16 & 27.26 & 1.57 & 31.9 & 22.91 & 3.39 & 1166 \\
\hline 22 & $\begin{array}{c}\text { Cordyceps } \\
\text { militaris }\end{array}$ & 12.78 & 4.84 & 25.52 & 1.73 & 21.1 & 34.03 & 5.40 & 1245 \\
\hline 23 & Sparassis crispa & 6.90 & 1.65 & 10.10 & 0.91 & 55.3 & 25.14 & 5.99 & 1075 \\
\hline
\end{tabular}

In terms of calories, edible fungi can be completely classified as low-calorie foods. Today when low-calorie light foods are being advocated, edible fungus products are gradually becoming the priority of people's diets. The analysis of Xu et al [8] on the nutritional composition of Pleurotus ostreatus, Lentinus edodes (Berk.) Sing and Flammulina velutiper (Fr.) Sing showed that the fat content of these three fungi accounted for a relatively low proportion in the nutritional composition. The results in Table 1 and Figure 4 showed that the edible fungi had a fat content of about $0.5-3.9 \mathrm{~g} / 100 \mathrm{~g}$, among which Morchella esculenta and Arimillaria mellea had the highest fat content, $3.89 \mathrm{~g} / 100 \mathrm{~g}$, and Auricularia auricula (L.ex Hook.) under wood had the lowest fat content, $0.46 \mathrm{~g} / 100 \mathrm{~g}$, respectively. 


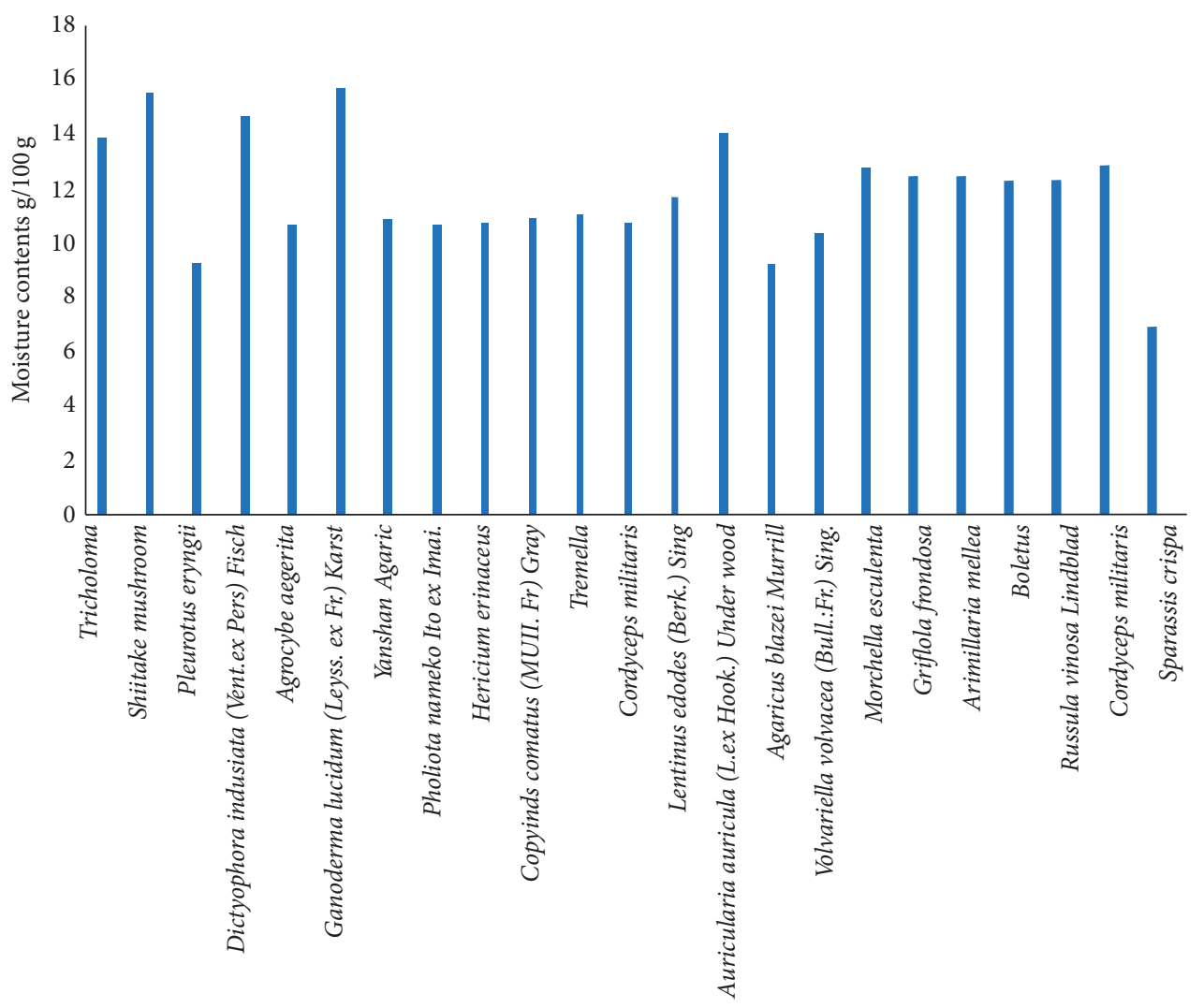

FIgURE 1: Moisture contents of 23 kinds of edible fungi.

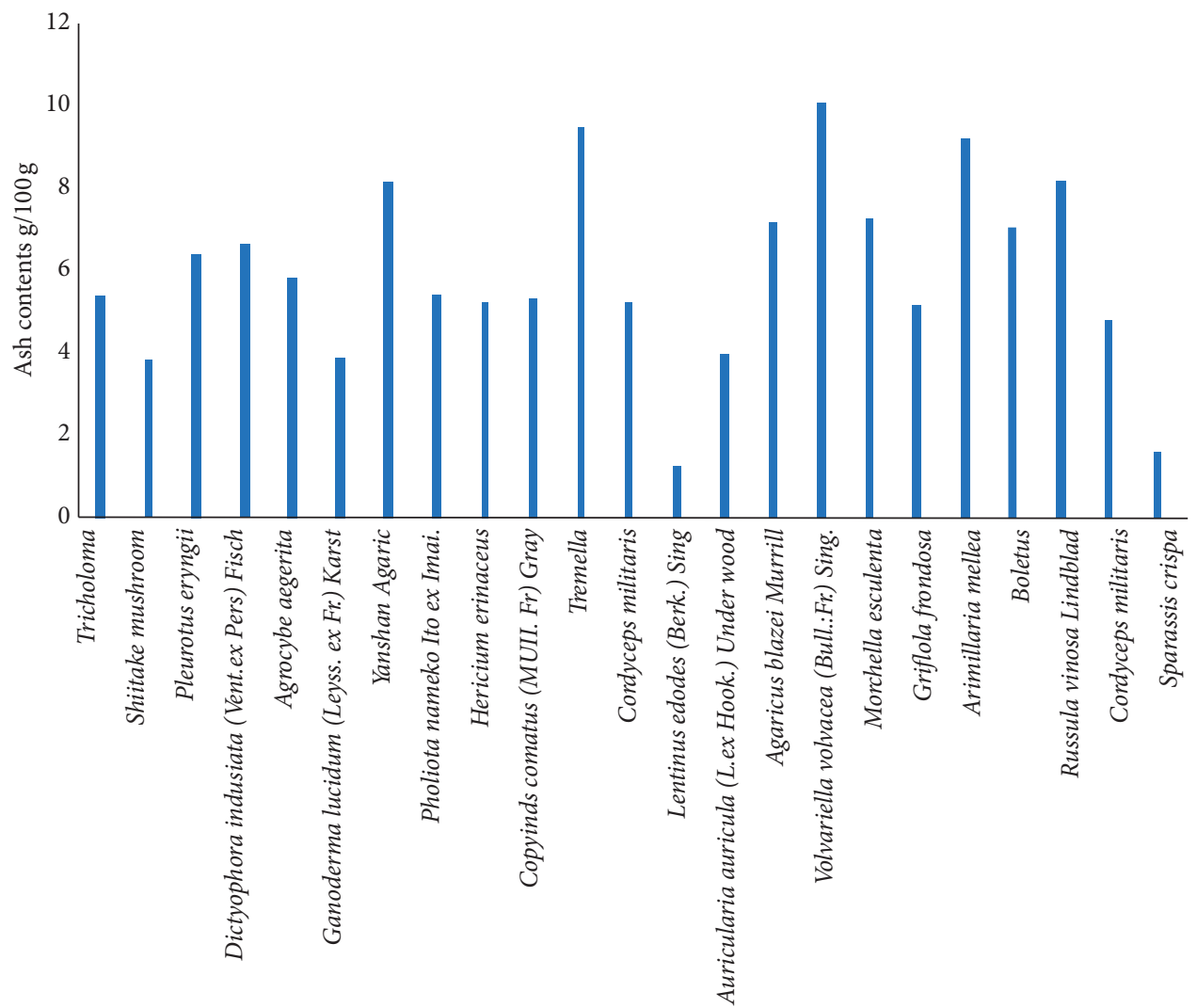

Figure 2: Ash contents of 23 kinds of edible fungi. 


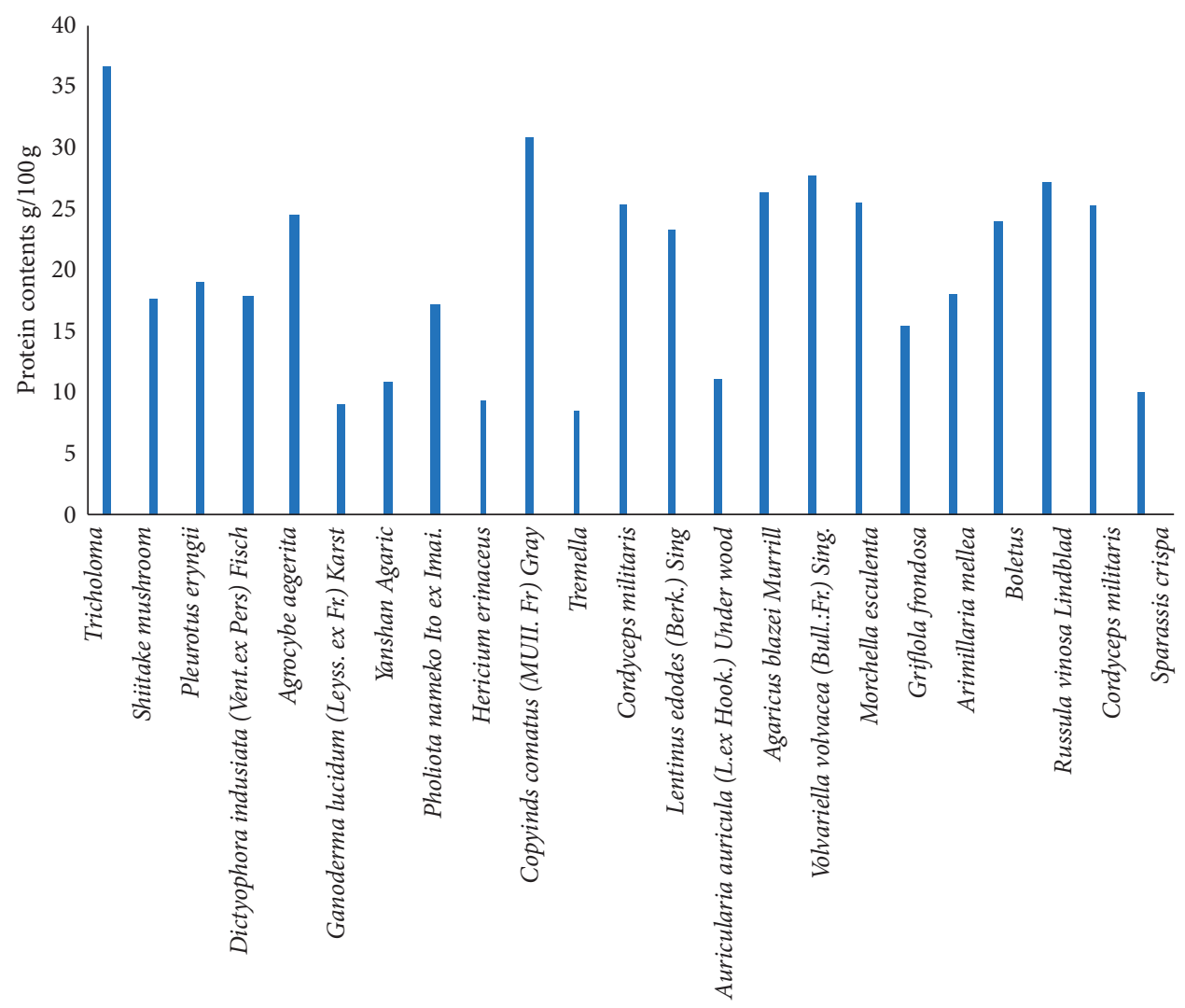

Figure 3: Protein contents of 23 kinds of edible fungi.

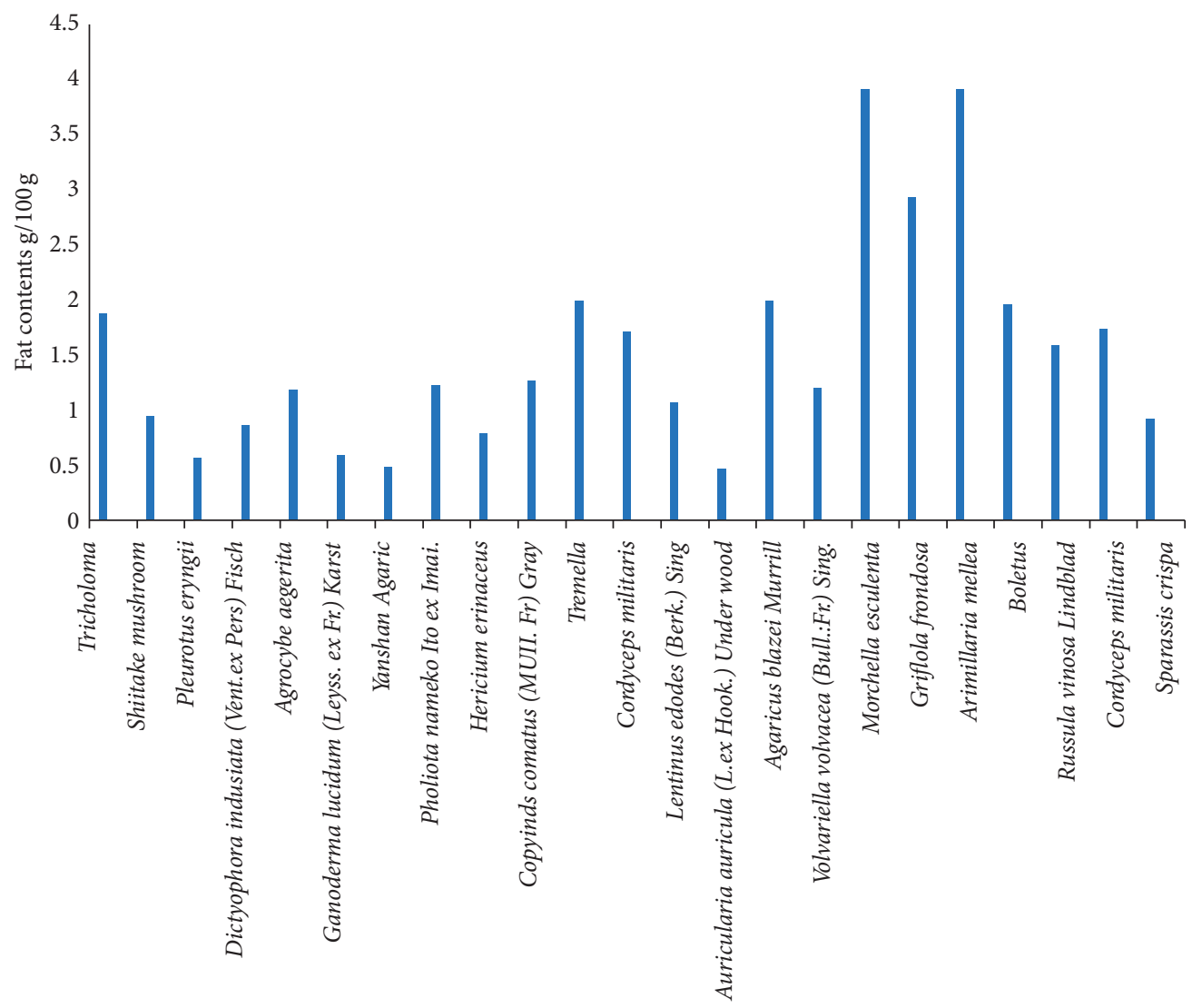

Figure 4: Fat contents of 23 kinds of edible fungi. 


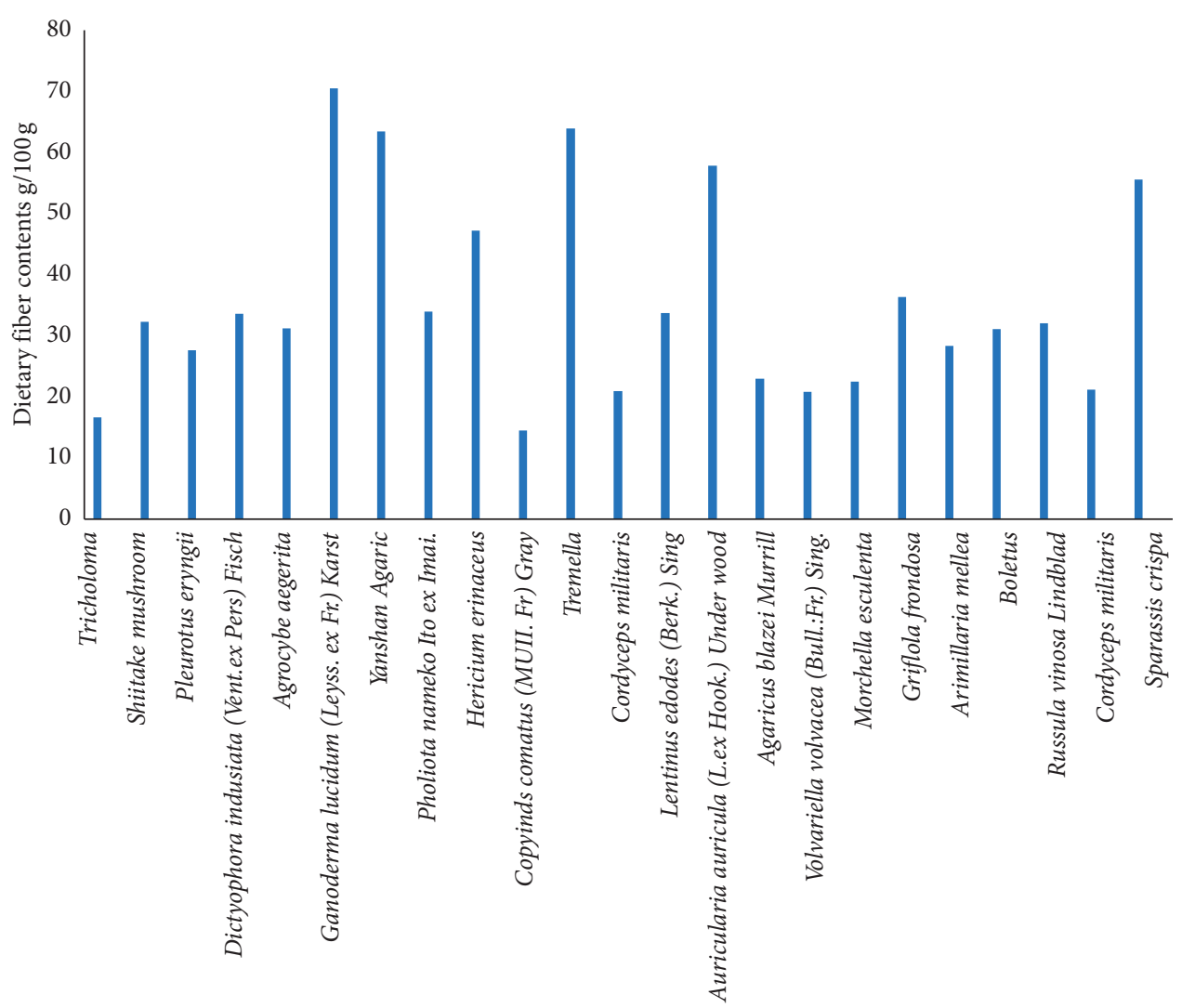

FIgURE 5: Dietary fiber contents of 23 kinds of edible fungi.

Dietary fiber refers to the sum of edible plant-based components, carbohydrates, and similar substances that cannot be digested and absorbed by the human small intestine, but can be partially or fully fermented in the human large intestine, including polysaccharides, oligosaccharides, lignins, and related plant substances. As an important raw material of functional foods, dietary fiber has been listed as the seventh nutrient just after protein, fat, saccharides, cellulose, minerals, and water, becoming a hotspot in food studies [9]. Dietary fiber is known as the "gut scavenger." Therefore, higher intake of edible fungi rich in dietary fiber can help prevent a variety of diseases and meet the requirements of changing the diet structure generally advocated at home and abroad [10].

At present, there are no dietary fiber standard substances both at home and abroad, so it is impossible to verify the accuracy of the enzymatic gravimetric method using a spiked recovery experiment. Yang et al. [11] verified it through the reproducibility in the laboratory, repeated the determination 6 times according to the test method, and calculated the RSD. According to the allowable deviation of the national standards, the absolute difference between the two independent determination results obtained under the repeatability conditions should not be greater than $10 \%$ of the arithmetical mean value, and the determination results showed a good reproducibility; the determination results of the content of total dietary fiber, soluble dietary fiber, and insoluble dietary fiber in the Auricularia auricula (L.ex Hook.) under wood sample showed that the sum of soluble dietary fiber and insoluble dietary fiber contents were consistent with the total dietary fiber content, indicating that the enzymatic gravimetric method was very accurate. Therefore, use of the enzymatic gravimetric method for determination of dietary fiber content could accurately reflect the actual content of dietary fiber. Table 1 and Figure 5 showed that there are five kinds of edible fungi having a dietary fiber content of more than 50\%, among which Ganoderma lucidum (Leyss. ex Fr.) Karst. had the highest dietary fiber content, $70.2 \mathrm{~g} / 100 \mathrm{~g}$. (Figure 6)

Polysaccharide is one of the main immunoregulatory and antitumor active substances in edible fungi. As an important functional factor of health food, it is widely present in various edible fungi. Therefore, the research and development of edible fungus polysaccharide is extremely promising. Chihara first discovered that lentinan not only inhibited the growth of S-180 sarcoma in mice but also prevented the carcinogenesis of chemical and viral tumors, and at the same time, it reduced plasma cholesterol and improved the body immunity [12]. Lentinan had become the polysaccharide studied most early and completely in edible 


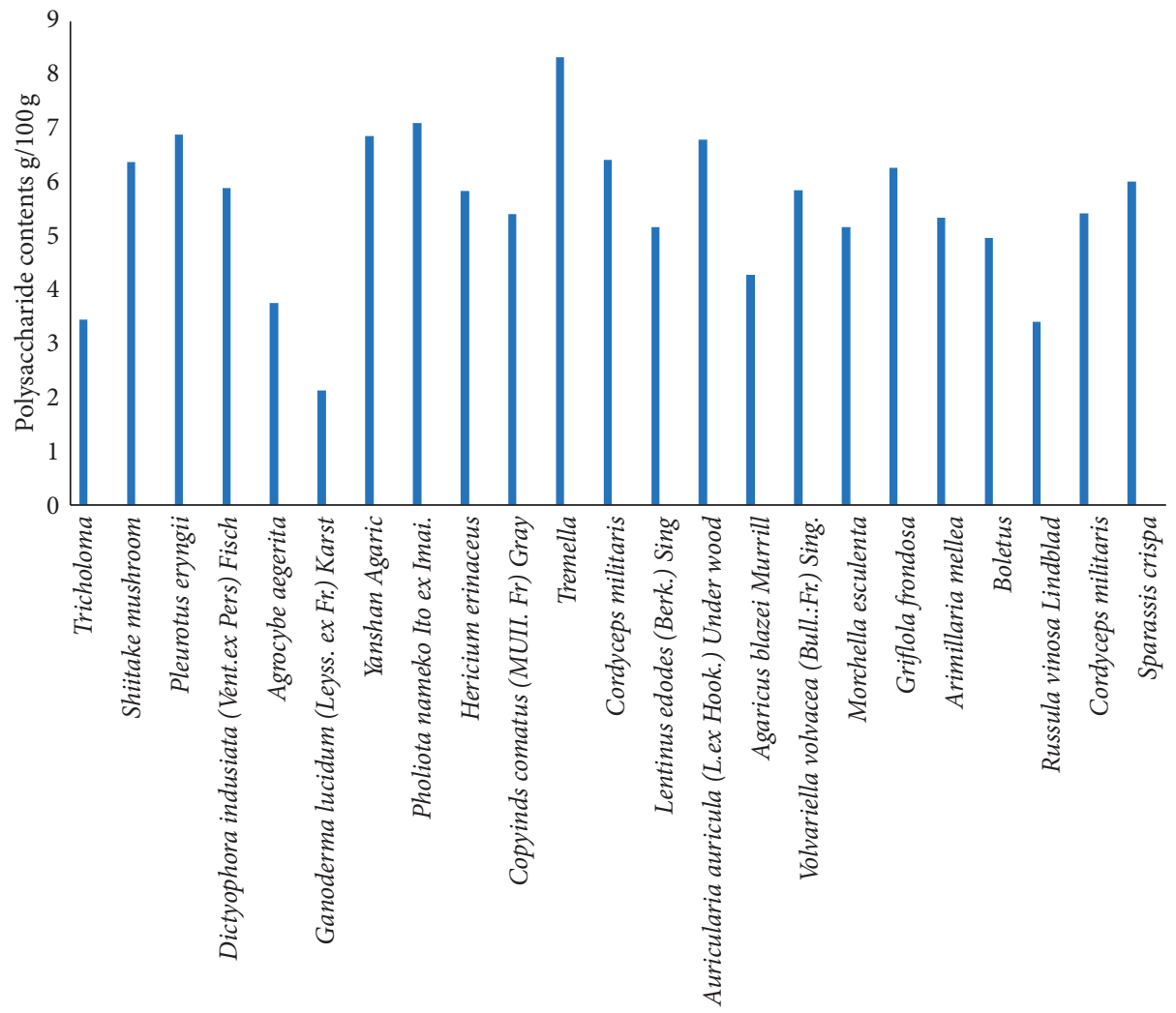

Figure 6: Polysaccharide contents of 23 kinds of edible fungi.

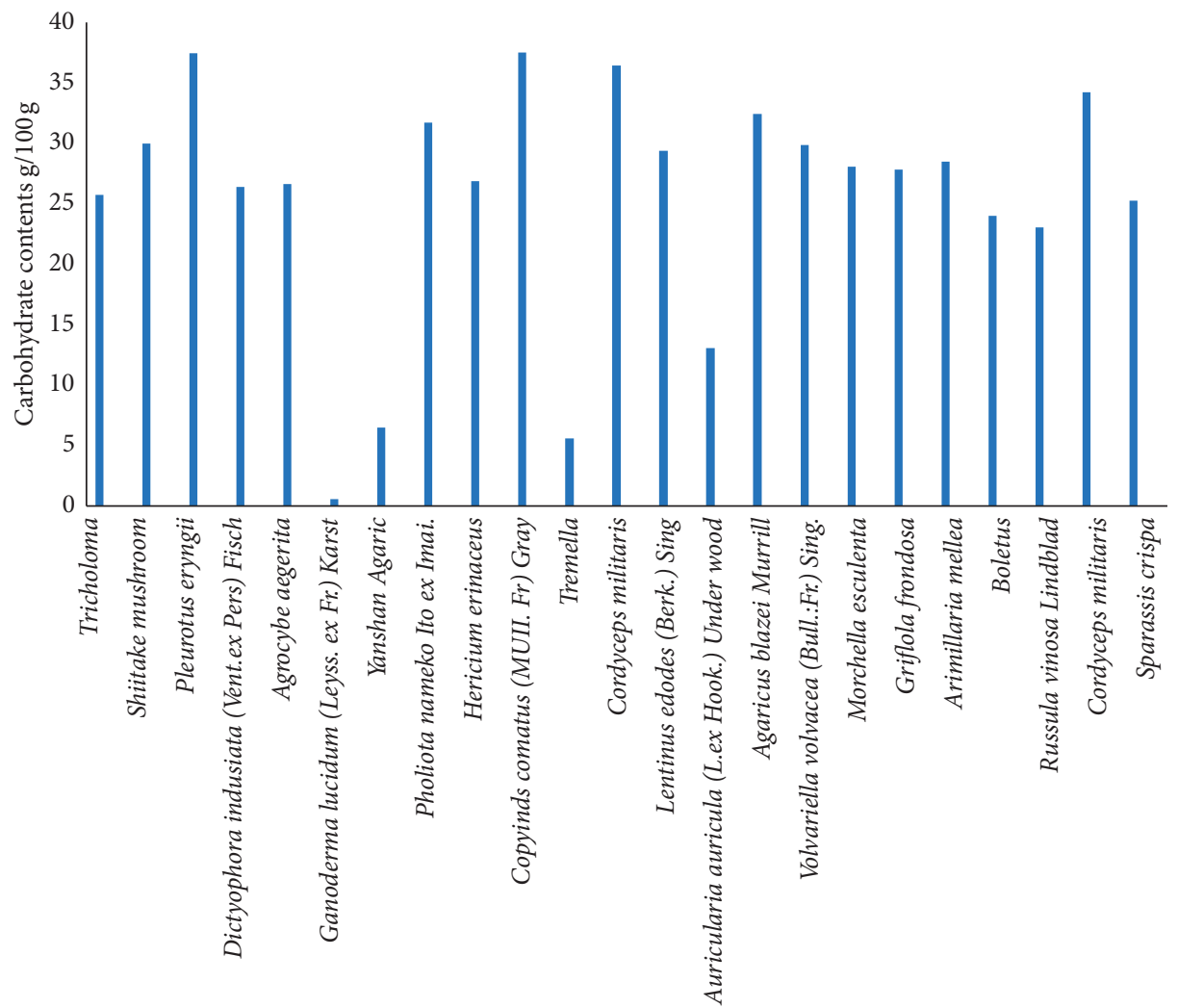

Figure 7: Carbohydrate contents of 23 kinds of edible fungi. 
fungus polysaccharides. Subsequently, ganoderan, pachymaran, Tremella polysaccharide, etc., have also been gradually studied in dept and have been proved to have immune regulation, antifatigue, anti-inflammation, antitumor, nerve protection, and other effects [13-15].

Colorimetric method is a traditional way for the determination of polysaccharide content. The most commonly used method is phenol-sulfuric acid method whose stability and accuracy are significantly better than those of the anthrone-sulfuric acid method and the orcinol-sulfuric acid method. Wang et al. [16] compared the phenol-sulfuric acid method and the anthrone-sulfuric acid method for the determination of polysaccharide content in Pleurotus nebrodensis mycelium, and the results showed that the phenol-sulfuric acid method is better. For determination of the absorbance of reaction solutions, the most commonly used method is the UV-vis spectrophotometry, which has a high precision, a good repeatability, and a relatively simple operation. With the development of technology, a more convenient method,enzyme linked immunosorbent assay (ELISA), has emerged. The microplate reader can simultaneously determine the absorbance of dozens of samples to be tested, avoiding the trouble of frequent replacement and cleaning of cuvettes. It is very quick and sensitive. At the same time, when a microplate reader is used to determine samples, only a few hundred microliters of liquid is needed, which can avoid the waste of reagents and raw materials under certain circumstances. Zhao et al. [17] used a microplate reader to determine the polysaccharide content in six kinds of edible fungi. The results showed that the ELISA had a higher stability, repeatability, and recovery rate. This method showed a greater accuracy in determination of the polysaccharide content. The results of this study showed that the polysaccharide contents in edible fungi were $2.1 \sim 8.3 \mathrm{~g} / 100 \mathrm{~g}$, and the Tremella polysaccharide content was $8.29 \mathrm{~g} / 100 \mathrm{~g}$, which was a rare edible fungus with great development prospects.

Carbohydrates include soluble sugars and cellulose. Soluble sugars are easily absorbed by the small intestine. Cellulose cannot be absorbed by the human body but has the role of a starch blocker. It can help promote intestinal peristalsis and assist in the treatment of obesity, diabetes, hypertension, and other diseases $[18,19]$. As it could be seen in Table 1 and Figure 7 , the carbohydrate contents of edible fungi were mostly $25 \sim 37 \mathrm{~g} / 100 \mathrm{~g}$, and the highest value is present in Copyinds comatus (MUII. Fr) Gray, 37.32 g/100 g.

\section{Conclusion}

In this study, Volvariella volvacea (Bull.:Fr.) Sing. has a higher content of ash, protein, and carbohydrates, indicating that it is high in freshness, rich in various nutrients, and has a high comprehensive nutritional value. Yanshan Agaric has an appropriate moisture content, a mediate protein content, and a low carbohydrate content. It is an ideal food for obese and thin people. Tremella has an appropriate moisture content, an ash content only second to Volvariella volvacea (Bull.:Fr.) Sing., and low carbohydrate and protein contents, indicating that it is high in freshness and rich in mineral elements, which is beneficial to the metabolism of the human body and promotes growth and development. Copyinds comatus (MUII. Fr) Gray is high in sugar and protein. It is not suitable for people with hypertension and diabetes. However, the functional sugar therein can enhance the body's resistance and antitumor ability, etc. [20], which is suitable for healthy people.

In this study, through the detection and analysis of basic nutritional composition, it could be seen that the 23 kinds of common edible fungi have a higher protein content and a lower fat content, all of which can be regarded as high-protein and low-fat foods. The determined 23 kinds of edible fungi are comprehensive and rich in nutrients and with a reasonable nutrient proportion and contain polysaccharides and other bioactive substances. So, it has far-reaching development potential. This study provides a theoretical basis for the deep processing and scientific consumption of edible fungi.

\section{Data Availability}

The data used to support the findings of this study are available within the manuscript.

\section{Conflicts of Interest}

The authors declare that they have no conflicts of interest.

\section{Acknowledgments}

This work was funded by National Key Research and Development Program of China (Project no. 2019YFC1606400) and Special Program for Technical Support of the State Administration for Market Regulation (2020YJ007).

\section{References}

[1] L. Li, "Research progress of nutritional components and activity of edible fungi," Food Research and Development, vol. 36, no. 12, pp. 139-142, 2015.

[2] Y. Chen, "Nutritional composition and health care effects of edible fungi," Edible and Medicinal Mushrooms, vol. 22, no. 1, pp. 14-18, 2014.

[3] X. Teng, "The nutrition of edible fungi and the effect of improving dietary structure," Agriculture and Forestry Technology, no. 20, p. 169, 2007.

[4] N. Cohen, J. Cohen, M. D. Asatiani et al., "Chemical composition and nutritional and medicinal value of fruit bodies and submerged cultured mycelia of culinary-medicinal higher basidiomycetes mushrooms," International Journal of Medicinal Mushrooms, vol. 16, no. 3, pp. 273-291, 2014.

[5] A. Z. Woldegiorgis, D. Abate, G. D. Haki, and G. R. Ziegler, "Antioxidant property of edible mushrooms collected from Ethiopia," Food Chemistry, vol. 157, no. 16, pp. 30-36, 2014.

[6] K. Pavel, "A review of trace element concentrations in edible mushrooms," Food Chemistry, vol. 69, no. 3, pp. 273-281, 2000.

[7] J. Yue, "Mushroom treasure-tricholoma," China Inspection and Quarantine, no. 4, p. 41, 1998.

[8] H. Xu, C. Bian, and J. Wang, "Determination of nutritional components in 3 kinds of edible fungi," Journal of Anhui Agricultural Sciences, vol. 38, no. 14, pp. 7544-7546, 2010.

[9] M. Elleuch, D. Bedigian, O. Roiseux, S. Besbes, C. Blecker, and H. Attia, "Dietary fibre and fibre-rich by-products of food processing: characterisation, technological functionality and 
commercial applications: a review," Food Chemistry, vol. 124, no. 2, pp. 411-421, 2011.

[10] J. Wu, "The health care function and the function of improving food structure of edible fungi," Edible Fungi of China, vol. 22, no. 4, pp. 9-11, 2003.

[11] X. Yang, X. Li, Z. Tang et al., "Determination of dietary fiber in different mushrooms by enzyme-weight method," Journal of Capital Normal University (Natural Science Edition), vol. 34, no. 6, pp. 12-15, 2013.

[12] L. Su, Y. Jiang, J. Luo et al., "Comparative study on physicochemical properties and immune activity of five kinds of edible fungi polysaccharides," Food Science, vol. 36, no. 13, pp. 252-256, 2015.

[13] S.-q. Huang and Z.-x. Ning, "Extraction of polysaccharide from Ganoderma lucidum and its immune enhancement activity," International Journal of Biological Macromolecules, vol. 47, no. 3, pp. 336-341, 2010.

[14] B. Chen, "Optimization of extraction of Tremella fuciformis polysaccharides and its antioxidant and antitumour activities in vitro," Carbohydrate Polymers, vol. 81, no. 2, pp. 420-424, 2010.

[15] M.-K. Lu, J.-J. Cheng, C.-Y. Lin, and C.-C. Chang, "Purification, structural elucidation, and anti-inflammatory effect of a water-soluble 1,6-branched 1,3- $\alpha$-d-galactan from cultured mycelia of Poria cocos," Food Chemistry, vol. 118, no. 2, pp. 349-356, 2010.

[16] S. Wang, Y. Liu, S. Zhao et al., "Comparison of two methods for determining mycelium polysaccharides of Pleurotus ostreatus," Food Research and Development, vol. 32, no. 9, pp. 162-164, 2011.

[17] Y. Zhao, R. Bi, and D. Mu, "Determination of polysaccharide content in 6 kinds of edible fungi by using microplate reader," Edible Fungi, no. 1, pp. 59-61, 2013.

[18] K. Khatun, H. Mahtab, P. A. Khanam, M. A. Sayeed, and K. A. Khan, "Oyster mushroom reduced blood glucose and cholesterol in diabetic subjects," Mymensingh Medical Journal, vol. 16, no. 1, pp. 94-99, 2007.

[19] J. Wang, P. Wang, and G. Sun, "A traditional edible fungiPleurotus ostreatus," Academic Periodical of Farm Products Processing, vol. 5, pp. 140-141, 2012.

[20] Z. Liu and H. Wang, "Research and development of edible fungi functional food," Food Technology, no. 1, pp. 29-31, 2007. 